\title{
Investasi Daerah dalam Teori Modernisasi
}

\author{
Dodik Wahyono \\ Sekolah Tinggi Ilmu Administrasi Panglima Sudirman Surabaya \\ Email: dodik@stiapas.ac.id
}

\begin{abstract}
Abstrak:
Penelitian ini bertujuan untuk mengetahui investasi daerah menurut teori modernisasi. Metode deskriptif kualitatif adalah metode yang digunakan dalam penelitian ini dengan studi kepustakaan sebagai teknik pengumpulan datanya. Hasil penelitian menunjukkan bahwa: 1) diharapkan kebijakan tersebut mampu mendorong pemerintah di daerah membuat peraturan-peraturan yang mengakomodasi kepentingan investor, 2) investasi merupakan suatu konsep teori modernisasi, yang sangat relevan bila digunakan untuk melihat atau menganalisis terkait adanya kebijakan obligasi daerah atau kebijakan untuk mendatangkan investor asing atau investor dalam negeri, dan 3) dibutuhkan kerjasama antar daerah guna mengurangi ketimpangan antar daerah dan ketimpangan potensi yang dimiliki di setiap daerah.
\end{abstract}

Kata Kunci: investasi, teori modernisasi

\begin{abstract}
:
This study aims to determine regional investment according to modernization theory. Qualitative descriptive method is the method used in this research with literature study as the data collection. The results of the study are that: 1) it is hoped that the policy can encourage local governments to make regulations that accommodate investors, 2) investment is a concept of modernization theory, which is very relevant when used to view or analyze the existence of regional bond policies or policies for so investors. foreign or domestic investors, and 3) inter-regional cooperation is needed to reduce inter-regional and regional potentials.
\end{abstract}

Keywords: investment, modernization theory

\section{Pendahuluan}

Suatu keberhasilan pembangunan dapat mudah dinilai terkait perubahan pada fisik atau pembangunan infrastruktur. Sejak orde baru hingga sekarang orientasi pembangunan pada infrastruktur yang memadai, komitmen pemerintah dalam pembangun infrastruktur terejawantahkan pada program pembangunan: infrastruktur transportasi, jalan, pengairan, air minum dan sanitasi, telematika, ketenagalistrikan, dan pengangkutan minyak dan gas bumi yang dijadikan program repelita 1 hingga repelita ke5.

Sejak orde baru, orientasi pemerintah adalah pada pembangunrn infrastruktur yang sejak itulah kita terjerembab pada hutang luar negeri untuk pembiayaan pembangunan. Dengan orientasi pembangunan yang dimiliki orde baru dan didukung oleh negara maju, akhirnya mulai melirik akan hutang pada IMF (International Monetary Fund), World Bank dan WTO (World Trade Organization). Pasca kucuran dana segar dari luar negeri (hutang) rezim orde baru mulai berkembang dan mencapai masa kejayaan. Sesampai adanya doktrin akan istilah "Bapak Pembangunan" dan mulai mencapai stabilisasi.

Terciptanya stabilisasi dalam masa orde baru mulailah investor-investor asing masuk ke Indonesia di awal tahun 1950 dengan adanya pembelian persenjataan perang dan itu merupakan suatu tanda adanya globalisasi yang merupakan suatu strategi amerika 
dan inggris dalam melakukan penjajahan di tanah air dengan mulai hutang pada IMF dan mulai menanamkan permodalan. Sejak itu bangsa Indonesia mulai dianggap sudah mampu dan menjadi negara sedang berkembang.

Pasca tumbangnya orde baru sangat santer isu terkait dengan kebijakan otonomi daerah yang sebenarnya bukanlah sesuatu hal yang baru dalam penyelenggaraan pemerintahan di daerah sebelum negara Indonesia berdiri masih berupa kerajaan yang juga menganut adanya sistem otonomi ${ }^{1}$ meskipun dalam budaya hegemoni patriarki. Kebijakan otonomi daerah sudah mulai dibicarakan semenjak negara ini lahir. Bahkan dalam pasal 18 Undang-Undang Dasar 1945 telah dituangkan ide-ide otonomi daerah dalam penyelenggaraan pemerintahan negara oleh para founding fathers negara ini.

Selama lebih setengah abad berbagai kebijakan Otonomi Daerah telah dilahirkan sesuai dengan semangat zamannya (zeitgeist). Mulai dari UU Nomor 1 Tahun 1945, UU Nomor 22 Tahun 1948, UU Nomor 1 Tahun 1957, UU Nomor 18 Tahun 1965, Penpres Nomor 6 Tahun 1969, UU Nomor 5 Tahun 1974 dan terakhir dengan UU 22/1999. Selama masa itu pula terdapat perubahan dan pergeseran semangat Otonomi Daerah antara lain; otonomi daerah yang seluas-luasnya, otonomi daerah yang nyata dan bertanggung jawab serta otonomi daerah yang luas, nyata dan bertanggung jawab ${ }^{2}$.

Sudah 9 tahun reformasi telah merubah suasana di Indonesia, namun tak ada perubahan yang sangat mendasar, yakni masih tingginya angka kemiskinan, banyaknya pengangguran, yang merambat pada krisis nilai moralitas dan etika sehingga memunculkan penyakit-penyakit baru dalam susunan sosial di tanah air. Keadaan pahit ini perlu adanya suatu analisa kritis terkait paradigma pembangunan di Indonesia.

\section{Metode Penelitian}

Penelitian ini menggunakan metode deskriptif kualitatif. Metode penelitian kualitatif adalah suatu metode penelitian yang mengumpulkan dan menganalisis data berupa katakata dan perbuatan-perbuatan manusia tanpa ada usaha untuk mengkuantifikasikan data kualitatif yang telah diperoleh ${ }^{3}$. Sedangkan teknik pengumpulan data yang digunakan oleh peneliti adalah studi kepustakaan atau bahan pustaka.

\section{Pembahasan dan Hasil Penelitian Tujuan Investasi Daerah dalam Otonomi}

Dalam pembangunan bangsa kita tidak memiliki modal baik dalam budget atau pun modal sosial, sehingga dalam melakukan suatu perubahan negara kita bertumpu pada eksplorasi kekayaan alam demikian ini merupakan suatu langkah yang dilakukan oleh tiap-tiap negara dunia ketiga untuk mendapatkan modal dalam melakukan pembangunan merupakan suatu hal yang dijadikan solusi dalam pembangunan infrastruktur. Akan tetapi sejak orde baru yang pola pemerintahannya otoriter dan dari hasil eksplorasi bahan tambang di daerah berpusat di Jakarta sehingga ketimpangan sosial antara daerah dengan pusat sangat jauh yang mengakibatkan daerah-daerah sekarang banyak yang regresif dalam kondisi sosial, ekonomi, politik, dan pendidikan.

Dengan kondisi demikian maka diperlukannya suatu pemberdayaan di tingkat daerah, yakni adanya otonomi daerah guna meningkatkan dan mempercepat pembangunan dalam menghapuskan kesenjangan dan distorsi antara pemerintah pusat dan daerah. Pemberdayaan merupakan suatu konsep mengalihkan kekuatan atau

\footnotetext{
${ }^{1}$ Agus Dwiyanto, Reformasi Birokrasi Publik Di Indonesia (Yogyakarta: Gadjah Mada Univershy Pres, 2006).

${ }^{2}$ Haryanto, Perencanaan Dan Penganggaran Daerah Pendekatan Kinerja (Semarang: Badan Penerbit Universitas Diponegoro, 2008).

${ }^{3}$ Afrizal, Metode Penelitian Kualitatif: Sebuah Upaya Mendukung Penggunaan Penelitian Kualitatif Dalam Berbagai Disiplin Ilmu (Jakarta: PT Raja Grafindo Persada, 2015).
} 
mendelegasikan otoritas ke pihak lain atau juga sebagai upaya untuk memberikan kemampuan atau keberdayaan. Oleh karena itu, pemberdayaan daerah diperlukan bagi semua komponen yaitu pemerintah, masyarakat, dan swasta. Tanpa melibatkan seluruh komponen daerah, upaya pemberdayaan ini tidak akan mampu meningkatkan kapasitas dan bargaining position daerah. Jika hanya sebagian atau salah satu komponen saja yang terlibat, maka akan muncul ketimpangan yang dikhawatirkan mungkin akan memperbesar ketidakberdayaan di daerah dan berujung pada konflik birokrasi dan konflik sosial.

Salah satu aspek bidang ini yang perlu diberdayakan adalah investasi daerah. Investasi yang dimaksud adalah investasi yang dilakukan oleh pemerintah, masyarakat dan sektor swasta. Investasi pemerintah dibagi menjadi investasi fisik dan investasi non fisik. Investasi fisik yang dilakukan oleh pemerintah daerah antara lain pembangunan infrastruktur, yang bertujuan untuk menyediakan sarana dan prasarana guna mendorong pertumbuhan ekonomi dan meningkatkan pelayanan kepada masyarakat. Investasi non fisik adalah pengembangan kapasitas sumber daya manusia daerah berupa pemberian pelayanan kesehatan dan perbaikan gizi masyarakat, pemberian kesempatan pendidikan bagi anak usia sekolah, dan jaminan sosial lainnya, salah satunya dengan adanya SCR (Social Reach Responsibility).

Jenis investasi ini juga disebut human investment. Selain kedua bentuk investasi tersebut, bagi daerah yang mampu juga dapat berinvestasi melalui pendirian BUMD atau partisipasi dunia usaha untuk memperoleh keuntungan guna meningkatkan PAD bagi pengelolaan pemerintahan, pembangunan dan pengabdian kepada masyarakat. merangsang pertumbuhan ekonomi daerah dan pemerataan pendapatan masyarakat. Dengan banyaknya investasi dunia usaha di daerah, diharapkan semakin banyak lapangan pekerjaan yang dapat menampung angkatan kerja. Hal ini juga akan berdampak pada pengurangan laju urbanisasi.

Dalam investasi di pusat atau didaerah lebih dikuasai oleh inventor asing (PMA) dari pada investor dalam negeri (PMD) hal ini merupakan suatu ciri akan ekonomi kolonial ${ }^{4}$. Peningkatan investasi secara umum, Jawa dan Madura masih menjadi pilihan utama investasi baik dalam maupun luar negeri. Hal ini antara lain terlihat dari masih besarnya porsi investasi di kedua pulau ini. Namun demikian, terjadi perkembangan yang cukup signifikan pada wilayah lain, terutama Kalimantan, Sulawesi, dan Maluku, yang antara 1999 sampai dengan 2007 nilai investasinya mengalami peningkatan drastis. Selama kurang dari satu dasawarsa, PMDN wilayah tersebut naik masing-masing $1172 \%, 420 \%$, dan 4018\%. Sedangkan PMA naik mencapai 2284\%, 4288\%, dan 7464\%. Kita dapat menduga bahwa endowment resources, terutama sumber daya alam (SDA) dan sumber daya manusia (SDM) yang relatif murah menjadi salah satu faktor pendorong utama perkembangan ini.

\section{Relevansi Teori Modernisasi dalam Investasi di Daerah}

Investasi merupakan suatu teori modernisasi yang menganut konsep pemikiran Roy Harrod dan Evsey Domar yang lebih pada aliran ekonomi yang berpikir investasi modal merupakan langkah awal, yang membandingkan Negara industri dan Negara agraris sebagai Negara dunia ketiga ${ }^{5}$, menganggap kemiskinan di Negara dunia ketiga dikarenakan minimnya modal dan masalah keterbelakangan adalah masalah modal, yang pemikiran ini menghubungkan antara pertumbuhan ekonomi dengan tabungan dan investasi. Teori ini menekankan akan modal yang besar untuk menaikkan pendapatan penghasilan yang mencukupi akan kebutuhan dasar masyarakat. Bila dalam prespektif di

\footnotetext{
${ }^{4}$ Revrisond Baswir, Bahaya Neoliberalisme (Yogyakarta: Pustaka Pelajar, 2009).

${ }^{5}$ Rahayu Sulistiowati, "Teori Pembangunan Dunia Ketiga Dan Pengaruhnya Terhadap Pembangunan Nasional," Publica 1, no. 1 (2011).
} 
Indonesia investasi sejak tahun 1950, investasi kearah eksplosari hasil pertambangan minyak, gas tambang lain-lainnya. Dan dimasa otonomi arah investasi bukan hanya pada eksplorasi hasil tambang melainkan sudah kearah pada kearifan local atau investasi pada potensi-potensi yang di miliki daerah

Dengan teori tabungan dan investasi merupakan hal yang masih digunakan sebab dalam Negara dunia ketiga terkendala modal untuk menciptakan usaha - usaha dalam mensejahterakan rakyat, sehingga dengan investasi dapat menambah modal dalam pembangunan yang hasil dari eksplorasi pertambangan dan inestasi untuk membuka lapangan kerja yang juga diharapkan akan melakukan pembangunan dan mamacu pertumbuhan ekonomi yang akan meningkatkan taraf hidup rakyat, sering terjadinya kegagalan pasar yang dimonopoli pemerintah, investasi bisa juga dialokasikan pada sektor-sektor publik, seperti halnya pendidikan, kesehatan, kredit, listrik, air, transportasi dan lainnya yang selama ini pemerintah kurang optimal dan bisa dikategorikan gagal dalam menyelenggarakan barang publik (public goods).

\section{Analisa Investasi di Daerah Dalam Paradigma Pembangunan}

1. Investasi sebagai modal dalam otonomi Daerah

Kebijakan yang dikeluarkan Pemerintahan Departemen Keuangan (Depkeu) terus melakukan improvisasi untuk pemberian penghargaan kepada pemda (pemerintah daerah) dalam bentuk intensif. Ke depan, yang dijadikan acuan tidak hanya kinerja keuangan dan tingkat kesejahteraan di tahun depan tetapi juga menambah parameter kemampuan daerah dalam mendatangkan investor. Maksud dan tujuan kebijakan tersebut adalah untuk menumbuhkan atau mendatangkan investor di sebuah daerah.

Dan tujuan kebijakan baru itu diharapkan mampu mendorong pemerintah di daerah membuat peraturan-peraturan yang mengakomodasi kepentingan investor. Tak hanya perizinan, tapi juga pajak daerah. Jangan sampai perda (peraturan daerah) membuat investor enggan menanamkan di daerah, Mulai 2009, Depkeu telah menilai kinerja-kinerja daerah yang berhak mendapatkan insentif yang merupakan komitmen politik pemerintah pusat untuk memotifasi perbaikan pengelolaan pemerintah daerah. Berdasarkan informasi ${ }^{6}$ juga telah menunjuk 54 daerah yang terdiri 45 kota/kabupaten dan 9 provinsi yang layak mendapatkan insentif. Total pemerintah telah menganggarkan dana mencapai Rp 1,38 triliun. "Besarnya insentif antara Rp 18 miliar sampai Rp 38 miliar. Dana itu bakal kami masukkan dalam APBD 2010,"7.

Dari penanaman modal selama ini yang menjadi percontohan adalah Jakarta dan Jawa Timur, mengingat 2 daerah tersebut merupakan daerah yang padat penduduk dan dijadikan tujuan transmigrasi. Sehingga investor asing PMA atau dalam negeri PMDN masuk untuk menanamkan modal yang lebih pada dunia industri manufaktur

2. Investasi dalam Teori Modernisasi

Investasi merupakan suatu konsep teori modernisasi, yang sangat relevan bila digunakan untuk melihat atau menganalisis terkait adanya kebijakan obligasi daerah atau kebijakan untuk mendatangkan investor asing atau investor dalam negeri dan juga dapat menganalisis akan dampak investai terhadap keadaan social ekonomi dan budaya masyarakat, investasi sudah dilegalkan dalam perundang-undangan merupakan suatu dasar logika akan mengarah pada budaya liberalisme dan sadar atau tidak akan berdampak besar terhadap kehidupan masyarakat.

Meskipun Investasi merupakan langkah yang dilakukan oleh negara dunia ketiga seperti halnya Indonesia yang dalam mendatangkan investasi bukan hanya pada pada

\footnotetext{
${ }^{6}$ Sumber Data dari Media Jawa Pos (yang diposting sebagai studi case teori pembangunan)

${ }^{7}$ Dikutip dari; Mardiasmo yang juga Ketua Focus Group Desentralisasi Ekonomi-ISEI (Ikatan Sarjana

Ekonomi Indonesia)
} 
wewenang pusat saja melainkan juga bisa dilakukan oleh pemerintah daerah menurut Undang-Undang Nomor 33 Tahun 2004 tentang Perimbangan Keuangan Pemerintah Pusat dan Pemerintah Daerah ${ }^{8}$, memberikan kesempatan kepada daerah untuk memperoleh alternatif dana melalui penerbitan OD. Pernyataan ini secara jelas dinyatakan dalam Bab VIII, Bagian 7 tentang OD. Namun kesempatan tersebut tidak diimbangi dengan kesiapan masing-masing daerah untuk mengelola dan menata organisasi internalnya serta hubungannya dengan pihak eksternal. Oleh karena itu, dengan dibukanya keran otonomi daerah, apalagi dengan adanya undang-undang tersebut, rencana pemerintah daerah mengeluarkan OD menjadi rencana yang sangat menarik. Pembiayaan penerbitan obligasi memang merupakan alternatif metode pembiayaan yang relatif murah, dan dana yang bisa diperoleh lebih banyak, namun akan banyak konsekuensi yang harus ditanggung oleh pemerintah daerah.

Untuk mendapatkan investasi di daerah, semua daerah harus fokus pada peningkatan nilai investasi dan sekaligus memberdayakan investasi masyarakat bisnis lokal. Diharapkan dengan menarik investor besar, antara lain PMA dan PMDN ke daerah dapat memberikan dampak positif bagi perkembangan dunia usaha daerah, sehingga dapat mendorong pertumbuhan ekonomi daerah yang kemudian dapat berdampak pada peningkatan dan pemerataan pendapatan. kesejahteraan masyarakat di wilayah tersebut ${ }^{9}$.

3. Dampak Investasi dalam kehidupan masyarakat

Sadar atau tidak sadar merangsang atau menarik investor masuk merupakan dampak globalisasi dan untuk menghadapi globalisasi diperlukan kesiapan masyarakat terhadap persaingan dengan negara-negara lain, namun pada kenyataanya kita belum bisa memasuki era globalisasi sehingga merusak sendi-sendi perekonomian tanah air yang secara geografis Indonesia merupakan negara agraris dan maritim. Sehingga mengakibatkan kemiskinan yang akibat belum siapnya masyarakat akan globalisasi ataupun memang globalisasi adalah suatu bentuk penjajahan baru negara maju dengan adanya supra kosmos (suatu kekuatan diluar kekuatan konstitusi negara Indonesia) yang dikenal dengan IMF, WTO dan World Bank yang mempunyai andil besar untuk menentukan nasib negara-negara dunia ketiga.

Masuknya investasi ke daerah bertujuan dalam rangka memacu pertumbuhan perekonomian daerah sangat diperlukan dan membutuhkan kerjasama antar daerah guna mengurangi ketimpangan antar daerah dan ketimpangan potensi yang dimiliki di setiap daerah. Iklim investasi yang kondusif, mengarah pada jaminan keamanan dan kepastian hukum, pada dasarnya obligasi merupakan suatu sistem hutang yang dengan mekanisme baru untuk memperoleh dana setelah kebuntuan pamerintah untuk menyelesaikan masalah hutang dengan pemerintah luar negeri atau pihak swasta luar $^{10}$. Obligasi merupakan hakekat hutang dan biasanya bunga yang ditangungkan lebih mahal dari bunga bank pada umumnya yang mekanisme pembayaran juga mengangsur.

Bentuk obligasi didaerah-daerah bisa berbentuk pada fisik dan non fisik yang diatur dalam regulasi. Kebanyakan investor lebih mengarah pada investasi di bidang industri manufaktur yang dengan keberadaannya dapat menyediakan lapangan pekerjaan bagi masyarakat luas, ketertarikan investasi dalam manufaktur sebab ongkos jasa pekerja sangat relatif murah, namun pada kenyataanya meskipun ada undang-undang yang mengatur akan perburuhan di indonesai masih belum bisa memberi perlindungan kepada kaum buruh karena undang-undang lebih memihak

\footnotetext{
${ }^{8}$ Peraturan Pemerintah RI, Undang-Undang Republik Indonesia Nomor 33 Tahun 2004 Tentang

Perimbangan Keuangan Antara Pemerintah Pusat Dan Pemerintahan Daerah, 2004.

${ }^{9}$ Haryanto, Perencanaan Dan Penganggaran Daerah Pendekatan Kinerja.

${ }^{10}$ Didik J. Rachbini, Ekonomi Di Era Transisi Demokrasi (Jakarta: Ghalia Indonesia, 2001).
} 
pada investor dan lemahnya posisi pemerintahan terhadap kapitalisme, kondisi seperti ini merupakan suatu kosekwansi akan ketergantungan negara terhadap permodalan.

Bukti rill berdasarkan undang-undang ketenagakerjaan yang memihak akan investor yakni berlakunya outsourcing dan rendahnya UMR disebabkan dipengaruhi pihak perusahaan, tidak adanya jaminan keselamatan, jaminan kesehatan yang mencukupi.

Seperti halnya di Jakarta meskipun banyak para investor untuk menanamkan modal dalam bentuk perusahaan yang membuka lapangan pekerjaan seperti; GAP, KASOGI, ADIDAS dan merek ternaman lainnya menganggap buruh sebagai factor produksi yang semaunya memberlakukan tanpa adanya kemanusiaan dengan rendahnya tingakat gaji, minimnya jaminan kesehatan dan keselamatam belum lagi yang paling mendasar yakni pada kebijakan pemerintah dengan berbentuk perarutan perburuhan yang memihak pada investor. Sehingga kegagalan pemerintah dalam melakukan pembangunan yang malah berdampak pada menciptakan kemiskinan menjadi meningkat. Begitu juga kelemahan birokrasi dalam segi yuridis formalnya, serta rendahnya etika dan moral dan rendahnya bergaening position terhadapah investor yakni kasus bencana luapan lumpur lapindo yang merupakan ketidak siapan dan lemahnya birokrasi disebabkan ketergantungan dengan investor dan lemahnya ranah hukum sehingga bencana tersebut sampai sekarang penyelesaian akan akibat bencana luapan lumpur belum terselesaikan.

\section{Kesimpulan}

Akumulasi modal merupakan suatu teori yang relevan sebab dalam melakukan pembangunan membutuhkan modal yang tinggi. Akumilasi modal ini merupakan teori modernisasi yang di prakarsai oleh Harrod and Domar dengan teori investassi dan tabungan dengan merumuskan bahwa problem pembangunan dan keterbelakangan masyarakat merupakan didasari oleh tingkat investasi modal.

Di era-Otonomi berdasarkan Undang-undang nomor 33 tahun 2004 tentang Perimbangan Keuangan Pemerintah Pusat dan Pemerintah Daerah yang membuka peluang Daerah untuk mendapatkan pendanaan alternatif melalui penerbitan "Obligasi Daerah" disetiap daerah mempunyai weweang untuk mendatangkan dan meningkatkan investasi untuk melakukan pembangunan di sector yang mempunyai revenue lebih untuk mengembalikan hutang negara. ebab obligasi merupakan system model hutang yang dilegalkan dan penuh dengan resiko bila para pemerintah belum siap dalam manajemen pengelolaan maka obligasi merupakan boomerang bagi kita.

Obligasi daerah merupakan kosep teori investasi guna melakukan percetapan pembangunan yang berbasis local dan merupakan budaya masyarakat modern. Oleh sebab itu bila teori investasi mempunyai kelebihan dan kelemahan yang butuh untuk dianalisa dan revitalisasi guna mengoptimalkan obligasi dalam pembanguanan. Perhatian itu terkait akan penguasaan pemerintah terhadap inventasi, memprodak regulasi yang humanis, menempatkan masyarakat sebagai subjek pembangunan dan menciptakan keadilan serta melindungi kepentingan umum. Dan yang terpenting komitmen dan upaya pemerintah akan akumulasi modal sebagai pemberdayaan masyarakat (human resource development) dengan reorientasi pada pembangunan di bidang pendidikan dan membangun besik ekonomi kerakyatan.

\section{Daftar Pustaka}

Afrizal. Metode Penelitian Kualitatif: Sebuah Upaya Mendukung Penggunaan Penelitian

Kualitatif Dalam Berbagai Disiplin Ilmu. Jakarta: PT Raja Grafindo Persada, 2015.

Baswir, Revrisond. Bahaya Neoliberalisme. Yogyakarta: Pustaka Pelajar, 2009.

Dwiyanto, Agus. Reformasi Birokrasi Publik Di Indonesia. Yogyakarta: Gadjah Mada 
Univershy Pres, 2006.

Haryanto. Perencanaan Dan Penganggaran Daerah Pendekatan Kinerja. Semarang: Badan Penerbit Universitas Diponegoro, 2008.

Rachbini, Didik J. Ekonomi Di Era Transisi Demokrasi. Jakarta: Ghalia Indonesia, 2001. RI, Peraturan Pemerintah. Undang-Undang Republik Indonesia Nomor 33 Tahun 2004 Tentang Perimbangan Keuangan Antara Pemerintah Pusat Dan Pemerintahan Daerah, 2004.

Sulistiowati, Rahayu. "Teori Pembangunan Dunia Ketiga Dan Pengaruhnya Terhadap Pembangunan Nasional." Publica 1, no. 1 (2011). 